\title{
Sustainable Vegetable Production in California: Current Status, Future Prospects
}

\author{
T.K. Hartz \\ Department of Vegetable Crops, University of California, Davis, CA 95616
}

Issues of agricultural sustainability have increasingly become a focus of agricultural research and extension educational activity. Concerns over the apparent degradation of natural resources (soil erosion, loss of soil organic matter, pollution of surface- and groundwater with pesticides and nutrients), fears of increased pest resistance, food safety, and flagging farm profitability have prompted government, universities, and agricultural commodity groups to invest in developing and promoting alternative production methods that are more environmentally sensitive and economically sound.

The vegetable industry in five western states (Arizona, California, Idaho, Oregon, and Washington) dominates U.S. vegetable production, accounting for nearly half the acreage and more than $60 \%$ of the yield of fresh and processed vegetables; California alone produces nearly $40 \%$ of the national total (Table 1). The industry is characterized by large, highly mechanized farms. The use of irrigation is nearly universal, as is the use of synthetic pesticides and fertilizers. Given the geographical concentration of the industry, and the intensive production practices employed, the aforementioned environmental issues are of serious concern throughout the region.

Despite much research and educational activity over the past decade, the adoption of "sustainable" vegetable production practices in the West has been slow. In my experience, many growers consider most of these efforts to be irrelevant to their operations, primarily on economic grounds. The objectives of this review are to evaluate current vegetable production practices in California, discuss the major sustainability issues the industry faces, and highlight the roadblocks to adoption of commonly suggested alternative practices. While agricultural sustainability is often discussed in the context of the long term, the perspective presented here is confined to a shorter time period. The intent is to objectively evaluate the situation from the vantage point of the current generation of vegetable growers, the individuals who will be responsible for implementing change in the next 15-20 years. Consideration of this perspective may be useful for both researchers and extension educators who desire to significantly influence that change.

In evaluating the main issues regarding sustainability, this paper will focus on the production of lettuce (Lactuca sativa $\mathrm{L}$.) and processing tomato (Lycopersicon esculentum Mill.), the largest acreage and highest value

Received for publication 14 May 2002. Accepted for publication 5 Aug. 2002. vegetable crops produced in California. These two crops represent both the fresh-market and processing industries; the environmental and economic issues of concern to California lettuce and tomato growers are similar to those of growers of the other major vegetable commodities produced throughout the West. There is a substantial body of research on alternative practices for lettuce and tomato production in California to draw upon. Jackson and colleagues have reported extensively on the agroecology of lettuce production in the Salinas Valley (Jackson, 2000; Jackson and Stivers, 1993; Jackson et al., 1993, 1994; Wyland et al., 1995, 1996). The Sustainable Agriculture Farming Systems project (SAFS) conducted at UC Davis compared organic, low-input, and conventional farming systems for 12 years, using processing tomato as the primary cash crop (Clark et al., 1998a, 1998b; Clark et al., 1999a, 1999b; Colla et al., 2000; Gunapala and Scow, 1998). Lastly, Mitchell and colleagues conducted the Biologically Integrated Farming Systems project (BIFS), a 3-year comparison of alternative soil and pest management practices on 12 large, conventionally managed farms in the San Joaquin Valley (Andrews et al., 2002a, 2002b; Mitchell et al., 2001). Processing tomato was a primary test crop in these comparisons.

\section{Production and market trends}

Lettuce is grown on $\approx 85,000$ ha annually in California (CDFA, 2002), representing more than $70 \%$ of the total U.S. production (USDA, 2002a). Much of the acreage is concentrated in Monterey County, the heart of Salinas Valley production. About $65 \%$ of the production is iceberg (head) lettuce, the balance being leaf and romaine types. About $30 \%$ of total production is processed into packaged salad mixes, the rest marketed fresh as whole heads. Processing tomato is produced on $\approx 110,000$ ha annually (CDFA, 2002), representing more than $90 \%$ of the U.S. total (USDA, 2002a). Production is primarily in the Sacramento and San Joaquin Valleys in central California. The majority of production is processed into con- centrated paste for later remanufacturing into catsup, juices, and sauces.

The statewide area planted to head lettuce and processing tomatoes increased from 1986 to the early 1990 s, and thereafter fluctuated modestly in response to projected market conditions (Fig. 1, CDFA, 2002). Average head lettuce yield showed no clear trend statewide, but has increased substantially in recent years in Monterey County. Statewide processing tomato yields have increased significantly over this period.

Comparisons of enterprise budgets developed by Univ. of California Cooperative Extension show that preharvest production costs for head lettuce in Monterey County increased by $61 \%$ from 1986 to 2001 (Table 2), close to the overall rate of inflation $(60 \%$, as tracked by the consumer price index, CPI). With increased yield/ha over this period, cost per Mg of production (in constant 2001 dollars) declined substantially; however, increases in harvesting, cooling, and marketing charges (operations performed by the shipping company) left break-even cost for the grower essentially unchanged over this period. Processing tomato production cost estimates (including mechanical harvesting, an operation generally performed by the grower) increased $48 \%$ from 1989 to 2001 , close to the $45 \%$ increase in the CPI. With increasing yield, per unit production cost declined substantially over this period.

Cook's (2002) review of the fresh produce industry highlighted a number of market trends that have significant impact on vegetable growers. There has been rapid consolidation in both the retail and foodservice sectors of the industry over the past decade. Chain supermarkets now account for more than $80 \%$ of U.S. retail produce sales, while chain restaurants account for more than half of foodservice produce sales. This consolidation of retail and foodservice buying power has resulted in consolidation at the grower/shipper level as well, as these large retailers and foodservice customers demand services such as year-round supply, special packaging, just-in-time inventory control, and third-party certification of

Table 1. Production of fresh-market and processing vegetables, including potatoes, 2001, U.S.A.

\begin{tabular}{lcc}
\hline \hline State & $\begin{array}{c}\text { Area planted } \\
(1000 \mathrm{ha})\end{array}$ & $\begin{array}{c}\text { Production } \\
(1000 \mathrm{Mg})\end{array}$ \\
\hline California & 492 & 13,274 \\
Idaho & 171 & 2,926 \\
Washington & 147 & 3,313 \\
Oregon & 65 & 1,098 \\
Arizona & 57 & 955 \\
U.S. total & $\mathbf{1 , 9 9 1}$ & $\mathbf{3 3 , 9 2 0}$ \\
\hline Source: USDA National Agricultural Statistics Service (2002a, 2002b)
\end{tabular}



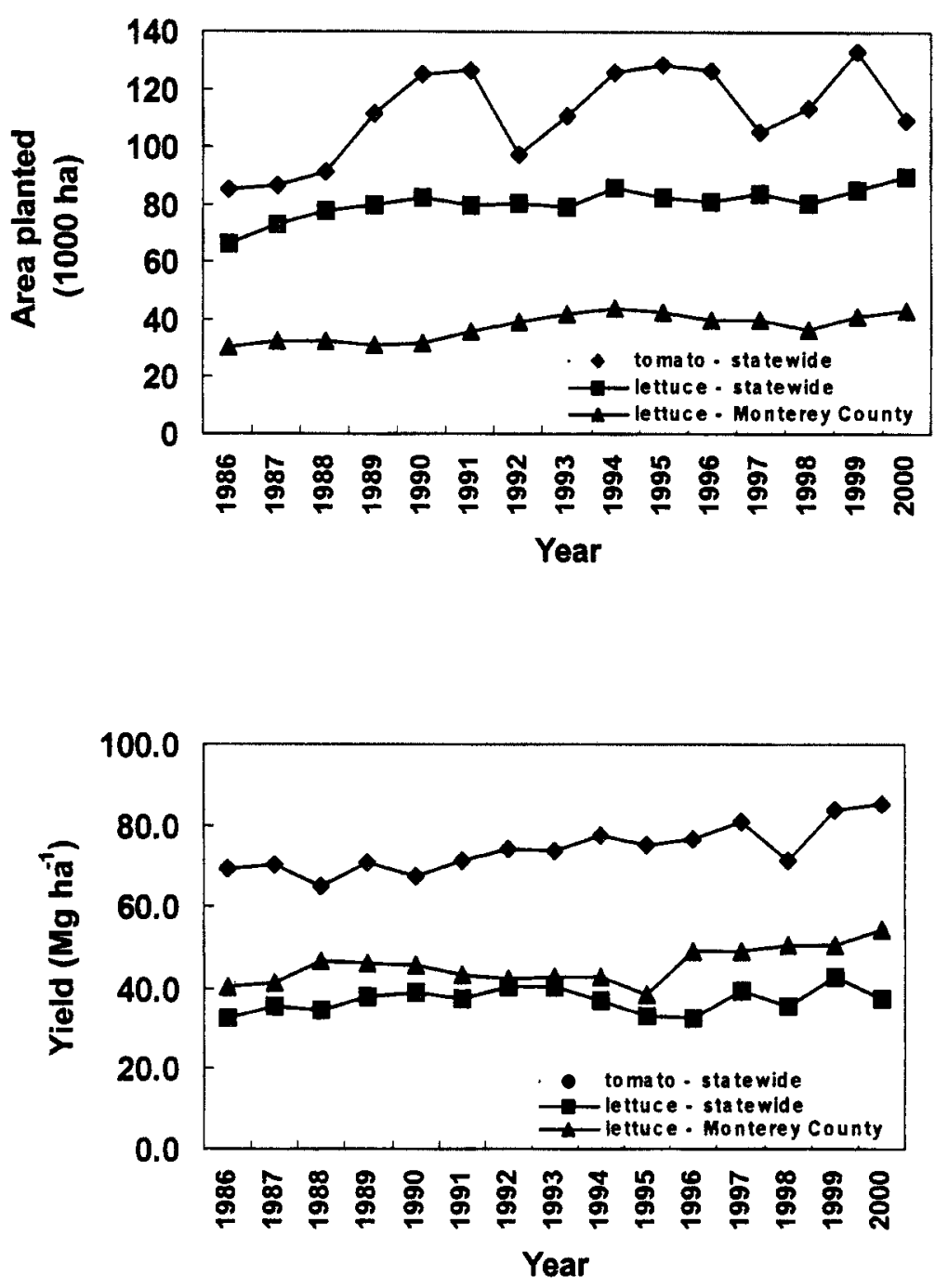

Fig. 1. Recent trends in planted area and average yield of head lettuce and processing tomato produced in California. Data from the California Dept. of Food and Agriculture (CDFA, 2002).

Table 2. Change over time in estimated production cost for head lettuce and processing tomato.

\begin{tabular}{|c|c|c|c|}
\hline \multirow[b]{2}{*}{ Year } & \multicolumn{2}{|c|}{ Production cost/ha ${ }^{2}$} & \multirow{2}{*}{$\frac{\text { Break-even cost }}{(\$ \mathrm{Mg})^{\mathrm{x}}}$} \\
\hline & Nominal \$ & Constant $\$$ & \\
\hline \multicolumn{4}{|l|}{ Lettuce } \\
\hline 1986 & 3225 & 5152 & 355 \\
\hline 2001 & 5184 & 5184 & 339 \\
\hline \multicolumn{4}{|l|}{ Tomato } \\
\hline 1989 & 2864 & 4141 & 59 \\
\hline 2001 & 4225 & 4225 & 50 \\
\hline
\end{tabular}

${ }^{2}$ Cost estimates developed by Univ. of California Cooperative Extension economists. Lettuce costs are for the Salinas Valley, and include preharvest inputs only, since harvesting is done by the shipping company; tomato costs are for the Sacramento Valley, and include mechanical harvesting costs, since that operation is normally done by the grower.

${ }^{y}$ Adjusted for inflation to 2001 dollars, using the Consumer Price Index (CPI). ${ }^{x}$ Constant (2001) dollars required to cover production and harvesting costs at the average yield for the year in question.

microbial food safety. The role of brokers and terminal markets is declining as direct buying by chain stores increases.

These trends suggest that small, independent fresh vegetable growers play a shrinking role in the overall fresh vegetable industry. Currently, $<2 \%$ of fresh fruit and vegetable sales nationwide are by direct to consumer methods (farmers' markets, pick your own, community supported agriculture, etc.). Even for organic production the trend is toward larger growers. In California the largest $2 \%$ of registered organic growers generate more than half of all organic sales (Klonsky et al., 2001). Despite rapid growth over the past decade, organic production represented $<2 \%$ of Cali- fornia vegetable production in 1998

In the processing tomato industry, consolidation has also occurred. There were significantly fewer California processing tomato growers in 2001 than in 1986, despite the large increase in acreage planted. There has been consolidation among processors as well, with a number of processing plants closing in recent years

Average wholesale (F.O.B.) price received for Monterey County iceberg lettuce varied widely from year to year, as is typical for a fresh vegetable commodity (Fig. 2, Monterey County Agricultural Commissioner, 2000). The overall trend was flat, in constant (2001) dollar terms. Comparing average price to estimated break-even price shows that lettuce production was not a very profitable enterprise over this period; in a number of these years growers actually lost money producing lettuce. The only highly profitable year was 1995 , when a spring flood in the Salinas Valley reduced production volume through much of the summer.

Average contract price (constant 2001 dollars) for processing tomatoes declined substantially since 1986 (Fig. 2, CDFA, 2002). Technological changes (use of hybrid varieties, transplants, drip irrigation, etc.) that have increased yields have allowed tomato production to remain a marginally profitable enterprise, but the trend is clearly toward declining profits. The effects of overproduction can be seen particularly in 1992 and 2000, years in which large product inventory from the previous season depressed contract price significantly.

In neither of these commodities is competition with imported product a significant influence on the low level of profitability. The two most significant factors are persistent overproduction (driven primarily by a lack of profitable alternative crops), and lack of market leverage with the chain supermarkets and restaurants that control both the retail and foodservice sectors of the industry.

\section{Trends in pesticide and fertilizer use}

All agricultural pesticide application in California has been done under a permit system since 1990 , which has allowed the California Dept. of Pesticide Regulation to compile annual statistics by commodity on the amount of pesticides used, and the frequency of application (CDPR, 2000). Pesticide use in statewide lettuce production was reasonably stable during the 1990s, with the exception of 1995 (Fig. 3). Most of the increased pesticide application in that year was attributable to the expanded use of the soil fumigants methyl bromide and chloropicrin (typically used in combination); the looming phaseout of methyl bromide, a very effective soil fumigant with long-lasting effects, stimulated the use of that chemical before that use was restricted. The application of nonfumigant pesticides (herbicides, insecticides, and fungicides) was relatively constant throughout the decade, despite the introduction of exotic insect species such as silverleaf whitefly [Bemisia agentifolii (Bel- 

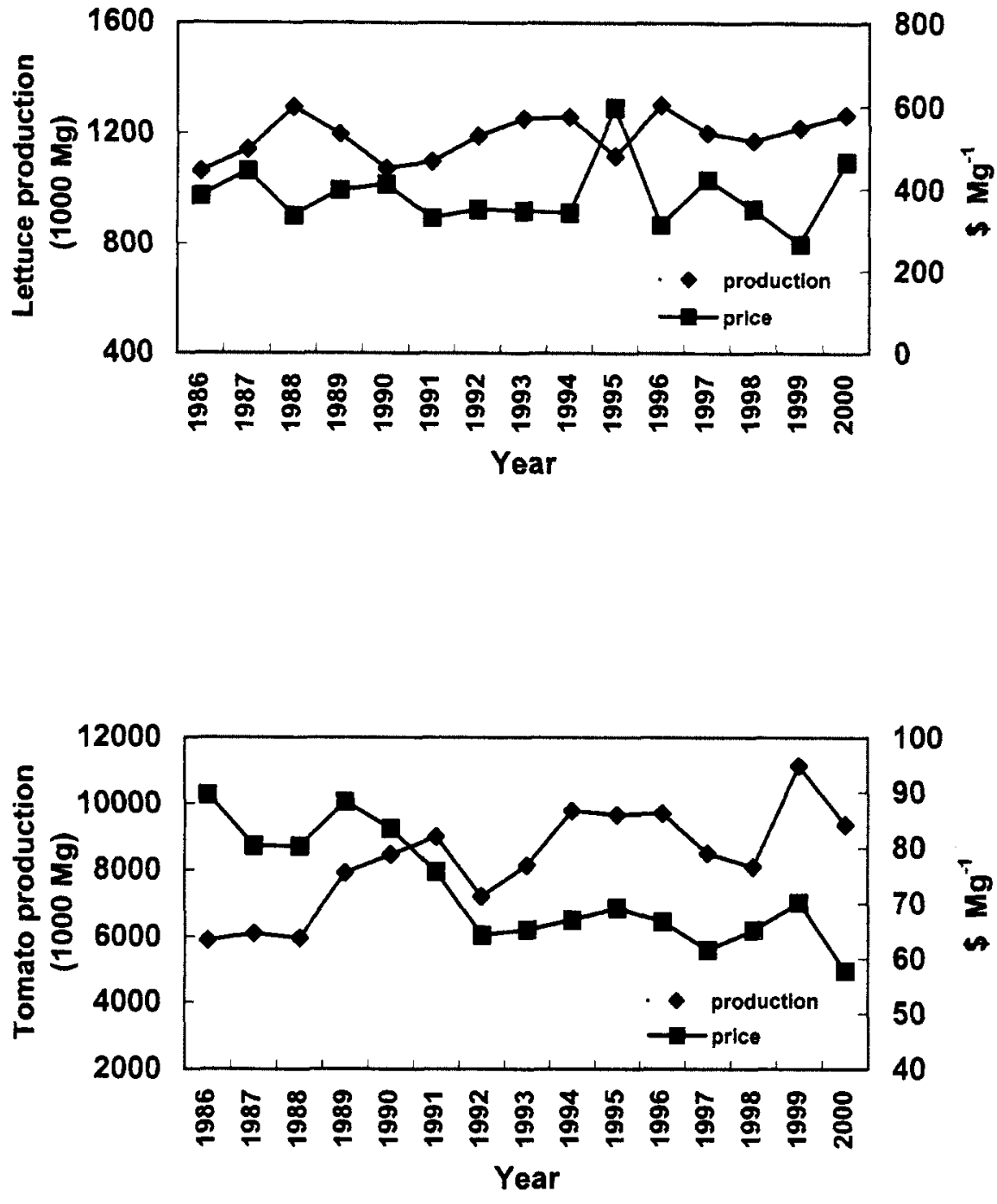

Fig. 2. Recent trends in total production and product value (constant 2001 dollars) for head lettuce (Monterey County only) and processing tomato (statewide). Data from the California Dept. of Food and Agriculture (CDFA, 2002).

lows \& Perring), Toscano et al., 1998] and black currant aphid [Nasanovia ribis-nifri (Mosley), Chaney, 2000] that have become significant pests on lettuce. The number of pesticide application permits requested per ha of lettuce production has declined in recent years.

Pesticide use on tomatoes increased substantially in 1992, and has been relatively steady since then (Fig. 3). The low pesticide use in 1990-91 may have been related to the drought conditions that prevailed in those years, and the effects of an abnormally cold winter that limited insect pests in 1991. In all years the majority of pesticide used was elemental sulfur (a natural product approved for organic production), applied both as a fungicide and a miticide; expanded use of sulfur accounted for the majority of the increase in pesticide use after 1991. The use of pesticides other than sulfur shows no clear trend over the decade, nor was there a consistent trend in the number of pesticide application permits requested per ha of production.

The Food Quality Protection Act (FQPA) of 1996 mandated sweeping changes in the registration process for pesticides. Under this act the U.S. Environmental Protection Agency (EPA) must review all new and currently registered pesticides based on aggregate risk of dietary exposure to all pesticides with a similar mode of action. Use of organophosphate and carbamate pesticides has been the foundation of pest control programs in most crops, including vegetables. FQPA may result in the loss of vegetable crop registration for many of these pesticides, and force dramatic changes in pest control programs. Most new registrations will be granted for "softer" pesticides with better toxicological profiles and less effect on nontarget organisms. That trend is already evident (Perrin, 1997). The tightening of human health and safety regulations governing farmworker exposure and pesticide drift from the site of application will further restrict pesticide usage.

The California Dept. of Food and Agriculture compiles annual statistics on fertilizer sales by county (CFDA, 2000). Since these statistics are not commodity-specific, caution in interpretation is warranted. For Monterey County and Yolo County (where processing tomato is the major cash crop) annual fertilizer sales per ha of irrigated cropland declined after 1986-90, remaining stable through the 1990s (Table 3). Since in both counties the ratio of vegetable crops (which are heavily fertilized) to irrigated row crops has increased over time, and yields have increased, these fertilizer sales statistics suggest that fertilizer use efficiency has improved.

Taken together, these pesticide and fertilizer data do not support the concept of a "chemical treadmill" (Benbrook et al., 1996; Horne and McDermott, 2001) that leads growers to increase fertilizer use or to use more, or more toxic, pesticides to counteract decreasing soil fertility and increasing pest resistance. While human health hazard, pest resistance, and environmental degradation resulting from agrichemical use are valid concerns, there is little objective evidence to suggest that conventional pesticide and fertilizer programs for these crops are becoming less effective or efficient.

\section{Status of soil resources}

Conventional farming practices have been widely characterized as destructive of soil tilth, fertility, and microbiological health. To the extent that current practices increase erosion, that criticism is clearly valid; erosion is a widespread problem in intensive vegetable production, due to factors such as excessive irrigation and infrequent use of vegetative cover during fallow periods. Also, current vegetable cropping practices (intensive tillage, infrequent cover cropping, or application of organic amendments) have unquestionably resulted in loss of soil organic matter and changes in soil microbial community structure and function. Soil organic $\mathrm{C}$ (SOC) has declined in some Salinas Valley soils by more than $40 \%$ since the early 1900 s (Wyland et al., 1996). Similar large declines in SOC due to conventional cropping practices have been documented elsewhere in the West (Karlen and Sharpley, 1994).

However, the suggestion that inherent soil productivity has been seriously harmed by conventional practices has been less convincingly demonstrated. Industry-wide, yields continue to increase with stable (water, pesticides, production cost) or declining (fertilizer) inputs. While it can be argued that improvements in other aspects of production (the use of improved cultivars, for example) mask the effects of declining soil quality, no net loss of productivity with current commercial practices has been seen. Indeed, the entire concept of soil quality based on organic matter content and associated parameters has been questioned (Sojka and Upchurch, 1999). While vegetable growers may recognize the potential benefits of modifying current practices to conserve or to increase soil organic matter (Andrews et al., 2002b; Mitchell et al., 2001), in most cases a compelling economic justification for change has not been made. 

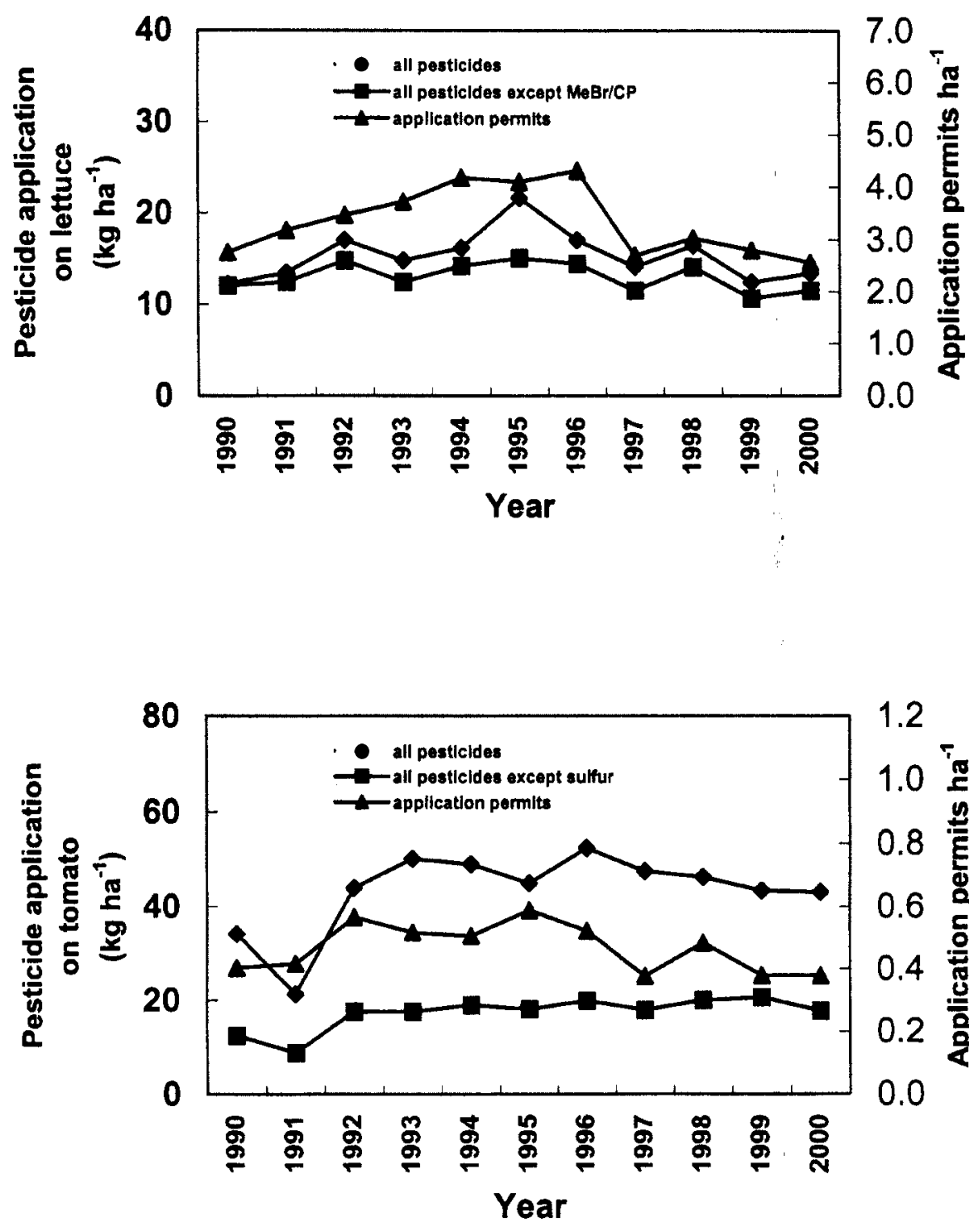

Fig. 3. Recent trends in pesticide use ( $\mathrm{kg}$ of active ingredient) for lettuce and tomato production in California. Data from the California Department of Pesticide Regulation (CDPR, 2000), and includes pesticide use on head, leaf and romaine lettuce, and both fresh market and processing tomato, because records do not clearly delineate among types of the same crop. $\mathrm{MeBr} / \mathrm{CP}=$ methyl bromide / chloropicrin.

\section{Status of water resources}

Virtually all vegetable production in the West is utilizes irrigation. Some production areas rely on groundwater, others on surface water from large-scale water projects. The long-term sustainability of current levels of agricultural water use is being questioned throughout the region, from both economic and environmental aspects (MacDonnell, 1999; Reisner, 1993). A major economic issue is the competition between agriculture and a rapidly expanding urban population for the finite supply of available water. Agriculture is by far the largest user of water in California and other western states, but in general it produces lower economic return per unit of water consumed than urban or industrial uses. Since the political reality throughout the region is that major new water developments are unlikely, it is inevitable that over time this economic competition will shrink the agricultural water supply. Significant water transfers from agricul-
7.0

6.0 '

5.0

4.0

3.0

2.0

1.0 0.0

$\therefore$

.
Project in Oregon and California in 2001 is an In the Columbia, Colorado, Sacramento, San Joaquin, and Snake River basins, political processes are in motion that likely will result in the transfer of significant quantities of water historically used for irrigation to environmental restoration. In most cases this water will be used to augment streamflow to improve survival of anadromous fish and other aquatic organisms considered to be threatened or endangered.

An associated issue is water quality. Nitrate pollution of groundwater is a significant problem in many areas of the irrigated West. The linkage of vegetable production with this problem is perhaps most obvious in the Salinas Valley, where more than $80 \%$ of irrigated cropland is planted to vegetable crops. The problem is clear; typical fertilizer $\mathrm{N}$ application significantly exceeds $\mathrm{N}$ removal in the harvested product. In areas like the Salinas Valley where double cropping is the norm, the pollution potential is magnified. Other western production areas (the Malheur and Umatilla River basins in Oregon, for example) have already been declared groundwater management areas, with mandated use of best management practices (BMP) to reduce further nitrate pollution, and timetables for compliance with water quality goals.

Pollution of surface water is also a significant concern. Runoff from vegetable fields, whether from rainfall or irrigation, can carry significant amounts of sediment, nutrients ( $N$ and $\mathrm{P}$ ), and pesticides. In the last decade nonpoint source pollution of surface water has become a focus of attention in the enforcement of the federal Clean Water Act. Water bodies in most of the major vegetable producing areas of the West are considered "impaired" for sediment load, temperature, nutrients and/or pesticides. The development of Total Maximum Daily Load documents (TMDL, specifying the amount of each pollutant permissible, and an implementation plan to attain that goal) have either been, or are in the process of being, 
developed. If rigorously enforced, the Clean Water Act has the potential to seriously disrupt the existing vegetable industry and force radical change.

To summarize the current situation, California lettuce and tomato growers have maintained a high level of productivity with stable or declining production inputs. As is the case throughout the West, the impetus to adopt more sustainable production practices will come primarily from government action on environmental issues, except where those practices reduce production cost. The following discussion reviews some commonly suggested steps toward more sustainable production in the context of the California vegetable industry, and highlights the roadblocks to adoption.

\section{Enhancing soil quality}

It is widely acknowledged that conventional vegetable production practices tend to reduce soil organic matter content, reduce soil microbial community diversity and activity, and adversely affect soil tilth. Conversely, the use of cover cropping, or the application of organic amendments, can reverse these trends (Andrews et al., 2002b; Lundquist et al., 1999; Poudel et al., 2001). Increasing the amount of organic matter returned to the soil can significantly influence soil microbial community structure and function (Bossio et al., 1998; Martini, 2001). Soil aggregate stability and water infiltration rate can be improved by increasing soil organic matter (Colla et al., 2000). Soilborne diseases may be suppressed in production systems that add large amounts of organic matter to soil (VanBruggen, 1995; Workneh and VanBruggen, 1994).

There are several reasons why, despite these demonstrable benefits, western vegetable growers have been slow to adopt alternative soil management practices. While current practices have historically reduced soil organic matter, in regions that have been farmed for decades an equilibrium tends to be established; assuming that high productivity has been maintained, this equilibrium level could be viewed as sustainable. Using the SAFS project to illustrate this point, after 11 years of an intensive rotation (wheat/tomato) soil organic matter was unchanged. Long-term studies in other locations have found similar results.

Secondly, soil building practices can have significant cost, and it has been difficult to consistently show that those costs are offset by increased productivity or reduction of other inputs. In the SAFS project, the organic (utilizing cover cropping and composted manure application) and low-input (utilizing cover cropping) farming systems averaged $13 \%$ and $3 \%$ lower tomato yield, respectively, than the comparable conventional system (Clark et al., 1999a), despite having significantly increased a number of soil attributes (SOC, microbial biomass $\mathrm{C}$ and $\mathrm{N}$, water infiltration rate) purportedly linked to soil quality. Over the final 6 years of the project (after the "transition" phase from prior conventional management) the organic system still averaged $6 \%$ lower yield, while the low input system was equivalent to the conventional system. In the BIFS project there were 14 site/year comparisons of tomato production with and without the use of cover cropping or compost application (Andrews et al., 2002). These alternative practices averaged $3 \%$ higher tomato yields, not enough to offset the additional cost (Mitchell, personal communication). Interestingly, all the yield advantage occurred in the first year of the study, with no benefit seen in the second and third years of alternative practices. Jackson and Ramirez (2001) found that compost application and cover crop use marginally improved lettuce yield, but not enough to offset additional costs (Jackson, personal communication).

Finally, alternative soil management practices can complicate other practices, and increase production risk. Cover crop incorporation in the spring may significantly delay planting and subsequent harvest date, particularly in wet years. Furthermore, cover crop residue can complicate seed bed preparation and planting of the crop, affecting stand establishment. Conservation tillage may require radical changes in weed control and irrigation practices, and may complicate harvest activity.

Despite these limitations, expanded use of cover cropping and conservation tillage is likely to increase in the future, and should be encouraged. Conventional tillage practices are expensive, constituting a significant portion of preharvest production costs; reducing the number of trips over the field, or the power requirement of the tractor, could offer substantial savings, provided yields can be maintained. Conservation tillage can also have significant environmental benefits, including erosion control and minimizing the loss of soil carbon to the atmosphere.

The potential environmental benefits of cover cropping are also significant, and it is these benefits that are likely to drive expanded use of this practice. Fall-planted cover crops can sequester large amounts of soil $\mathrm{NO}_{3}-\mathrm{N}$ that would otherwise be at risk of leaching (Jackson et al., 1993; Wyland et al., 1995, 1996). Cover crops also reduce winter runoff (Joyce et al., 2002; Miyao and Robins, 2000), and associated erosion and nutrient loss. The pest suppression activity of cover crops, in particular various Brassica species (Boydston and Hang, 1995; Olivier et al., 1999; Subbarao, 1998) can reduce the need for soil-applied pesticides or fumigants. The cost/benefit gap for cover cropping is reasonably narrow, and additional research and grower education, combined with grower incentives (recognition as an appropriate BMP to meet water quality goals, incentives from USDA conservation programs, etc.) will hasten and expand adoption.

\section{Reducing fossil fuel usage}

Conventional vegetable production is unquestionably energy intensive, with the largest energy inputs for agrichemical production (predominately $\mathrm{N}$ fertilizer) and fuel to power machinery and irrigation pumps. Alternative techniques such as organic production may reduce energy requirement for some inputs (agrichemicals, for example), but may increase energy use for others (composting, cover cropping, additional cultivation for weed control, etc.). Livingston (1995) compared the energy relationships of the organic, low input, and conventional cropping systems of the SAFS project from 1989 to 1992 (Table 4). He found that the conventional system had the highest energy input; however, due to higher yield, it also had the highest energy efficiency rating (food energy produced vs. fossil fuel energy expended). The low-input system, which included cover cropping and a minimal use of fertilizers and pesticides, was intermediate in both energy use and energy efficiency. The organic system was the least energy efficient; the lower energy input was more than offset by lower tomato yield. The more agrichemicalintensive a production system is, the more likely that an alternative system that reduces chemical use will be more energy-efficient. However, unless that alternative system improves water use efficiency, or substantially substitutes animal or human labor for machinery use, the potential for improving energy efficiency is likely to be modest.

Current postharvest handling practices are also energy-intensive, whether for a processing commodity (tomato) or a fresh market commodity (lettuce). Most California tomatoes are concentrated into bulk paste that can be shipped and stored without refrigeration for later processing into consumer products. With large, energy-efficient processing plants located near the production fields, the California industry operates relatively efficiently, and no significant improvement in overall energy efficiency would likely be gained from decentralization of the industry.

However, with lettuce a case could be made that decentralization of production could reduce overall energy use substantially. Currently, California lettuce is packed into singleuse cardboard boxes, vacuum cooled, and transported throughout the country on refrigerated trucks; all of these activities are energy-intensive. For the portion of the year that lettuce could be produced locally near Eastern population centers, particularly if direct-marketed with minimal packaging, overall energy efficiency may be substantially improved. However, significant decentralization of lettuce production (or that of any other vegetable crop) is unlikely in the near term, given current energy prices, and the realities of the existing produce marketing system in the United States. Another problem with decentralization of production is that crop yield in California is often substantially higher than elsewhere in the country; California has only $25 \%$ of the U.S. vegetable acreage, but produces $39 \%$ of total yield (Table 1). This minimizes any potential improvement in energy efficiency from decentralization.

\section{Reducing agrichemical usage}

Conventional vegetable production practices include the use of significant quantities of pesticides and synthetic fertilizers. In addi- 
Table 4. Energy output/input comparison for processing tomato production in the organic, low input, and conventional cropping systems of the SAFS project; average over the period 1989-1992.

\begin{tabular}{lccc}
\hline \hline Parameter & Organic & Low input & Conventional \\
\hline Energy input $\left(\mathrm{MJ} \cdot \mathrm{ha}^{-1}\right)$ & 2820 & 2890 & 2960 \\
Energy output $\left(\mathrm{MJ} \cdot \mathrm{ha}^{-1}\right)$ & 3230 & 3700 & 4180 \\
Output/input ratio & 1.1 & 1.3 & 1.4 \\
\hline
\end{tabular}

Source: Livingston, 1995.

tion to reducing fossil fuel usage, proponents of sustainable agriculture often advocate reducing or eliminating these chemical inputs to safeguard human health and minimize the ecological impact of farming. The pesticide application trends in California lettuce and tomato production suggest reasonably stable usage patterns. Significant strides have been made in the last decade to reduce farmworker exposure to pesticides. From a conventional grower perspective, using pesticides in a manner deemed safe by government regulatory agencies has maintained an adequate level of pest control despite a constantly changing pest complex. Viewed strictly from this standpoint there is little incentive for change, except to reduce cost or avoid additional governmental regulation.

There is widespread recognition within the industry that the development of pest resistance is a serious threat, and pest management programs are increasingly incorporating resistance management strategies (use of pest resistant cultivars, rotation of pesticides, etc.). The experience to date suggests that an appropriate blend of pest control techniques, combined with new pesticide development, is keeping the industry ahead of the pest complex. Some have characterized this approach as engaging in a "foot race with nature" (Lewis et al., 1997), but for these crops there is little evidence that this race is being lost.

That is not to suggest that significant reduction in pesticide usage is impractical, or that additional organic methods cannot be incorporated into conventional production systems. Intensive research into integrated pest management (IPM) systems for both crops has been conducted (Chaney et al., 2000; Flint, 1985, 1998; Zalom et al., 2000), and such research continues to be a high priority; scouting plans, action thresholds and nonchemical controls continue to be developed for many important pests. However, it is apparent that IPM could be more vigorously embraced by the industry. Nationwide, the majority of farmers rank low on the continuum from no IPM to biointensive IPM (Benbrook, 1996). In California, Trumble (1998; Trumble et al., 1994) and Chaney (2001; Chaney et al., 2000) have demonstrated the potential for reducing insecticide use in tomato and lettuce production, respectively, and for using more environmentally benign compounds when treatment is needed. Changes in the pesticide registration process brought about by the FQPA, and enhanced regulatory emphasis on water quality and human health and safety, provide added incentives for conventional growers to reevaluate current practices.

Pest management without synthetic pesticides is possible; substantial acreage of both lettuce and tomato are successfully produced organically. However, non-chemical production systems are generally more labor intensive, more costly, and their efficacy more variable; this reality is implicit in the assumption that organic produce must command a price premium to be economically viable. A significant portion of organic lettuce and tomato production in California is currently done by growers who also farm conventionally; the primary roadblock to the use of organic practices in their conventional fields is not lack of knowledge, but rather economic feasibility.

Management of soil fertility without synthetic fertilizers through cover cropping and the application of compost or other organic material (blood meal, fishery wastes, etc.) has been the focus of much of the sustainability research conducted over the past 15 years, and the broad principles of organic fertility management have been well defined. In actual field practice, however, effectively matching nutrient mineralization rate to crop need remains problematic; periodic $\mathrm{N}$ deficiency continues to be a common occurrence in organic vegetable production, particularly for high $\mathrm{N}$ demand crops. Added to this uncertainty is the significantly higher cost of $\mathrm{N}$ from organic amendments than from synthetic fertilizers. Viewed strictly from an economic perspective there is a significant disincentive to move toward organic fertility management.

Synthetic fertilizer use in vegetable production is without question a contributor to surface- and groundwater pollution. As is the case with pesticide use, substantial reduction in current fertilizer use without compromising productivity could be achieved simply by applying established management principles. Many growers use generalized fertilizer programs for each crop, without tailoring them for field-specific conditions. For example, preplant soil testing is common in the Salinas Valley, but many growers fail to act on the results; there continues to be widespread $P$ application in fields with soil test $P$ far beyond the threshold of agronomic response. Similarly, $\mathrm{N}$ application rates are seldom tied to any field-specific diagnostic. Pre-sidedress soil nitrate testing (PSNT) has the potential to reduce $\mathrm{N}$ fertilizer usage by $40 \%$ or more in Salinas Valley lettuce production (Breschini and Hartz, 2002a; Hartz et al., 2000). Krueskopf et al. (2002) also reported that sidedress $\mathrm{N}$ application on processing tomatoes could be reduced significantly by crediting residual soil $\mathrm{NO}_{3}-\mathrm{N}$. PSNT has been successfully applied to other vegetables such as cabbage (Brassica oleracea L., Heckman et al., 2002), celery [Apium graveolens L. var. dulce (Mill.) Pers., Hartz et al., 2000], and sweet corn (Zea mays L., Heckman et al., 1995).
Improved irrigation efficiency could also reduce fertilizer use, and off-site nutrient movement (Feibert et al., 1998). In the West, significant in-season leaching from rainfall is rare; with well-managed irrigation, nutrient losses can be controlled to a large extent. The majority of vegetable acreage is either sprinkler- or furrow irrigated. Evaluation of these irrigation systems in California has shown that distribution uniformity typically averages from $\approx 60 \%$ to $80 \%$ (Hanson, 1995). If the industry upgraded irrigation systems and improved management practices to consistently achieve the upper end of that efficiency range, both fertilizer usage and water pollution could be substantially reduced. Expanded use of drip irrigation, currently used on $<20 \%$ of vegetable acreage in the West, could further improve irrigation and fertilizer use efficiency, provided that appropriate management practices are adopted. However, the drip irrigation management practices currently employed may be less than ideal (Breschini and Hartz, 2002b). Increased regulatory pressure to meet water quality goals may be the impetus the industry needs to adopt improved fertilizer and irrigation practices. Research and grower education on practical tools to improve fertilizer use efficiency is likely to have more significant impact on the industry than activities targeting strictly organic fertility management techniques.

\section{Developing alternative crops and marketing strategies}

Crop diversification is often advocated as a step toward sustainability, for valid ecologi$\mathrm{cal}$ and economic reasons. From an ecological perspective, producing a variety of crops provides the opportunity for expanded crop rotation and enhanced biodiversity in the landscape. California growers do appreciate the value of rotation, and practice it to the extent they believe to be economically practical. In the Salinas Valley, for example, recent research has shown that soil incorporation of broccoli (Brassica oleracea) residue significantly decreased the severity of lettuce drop (caused by Sclerotinia sp.) of a subsequent lettuce crop (Subbarao, 1998). Broccoli is the second most widely grown vegetable crop in the Salinas Valley, and it is now nearly always followed by lettuce to take advantage of this benefit. The dilemma facing Salinas Valley growers is that the market for lettuce is significantly larger (and in general more profitable) than for broccoli, and no other crop that is economically profitable when produced on a large scale is available as an alternative rotational choice.

The situation is similar for processing tomato growers. Most also produce other vegetable or agronomic crops, and the potential benefits of crop rotation are nearly universally understood. The constraining factor is economics. Despite the steady erosion of the contract price for processing tomato, it has remained the most profitable option for many growers because the returns for other common local crops have barely covered production costs in recent years. 
There are also sound economic arguments for crop diversification. By producing a variety of commodities, the exposure to poor market prices for a given commodity is reduced. However, if prices for all major vegetable and agronomic crops are low, as has been the case in recent years, diversification is of little value. The strategy of diversification by producing specialty crops, or by marketing through alternative channels, may be useful for some individual growers, but it is impractical for the industry as a whole. Despite rapid growth in recent years, specialty vegetable crops represented only $6 \%$ of U.S. vegetable sales in 2000 (USDA, 2001). Even this overstates the market potential of specialties; vegetables already commonly grown in California such as chili pepper and romaine and leaf lettuce accounted for $61 \%$ of the U.S. total of specialty vegetables, with the majority of the remainder being tropical commodities unsuited for cultivation in the United States.

The opportunity for expansion of organic vegetable production is likewise constrained by market demand (Cook, 2002). Despite significant increases over the past decade, organic production accounted for $<2 \%$ of U.S. produce sales in 1999. Organic production remains a niche market, easily saturated; for example, by 2001 there was more land available in California for certified organic production of processing tomatoes than was needed to supply the market, and some established organic growers lost their production contracts. A number of major California lettuce grower/shippers now have land in organic production, and they are prepared to expand that production as the market warrants. Organic production is likely to continue to increase, but for the foreseeable future it will remain a small segment of the industry.

To put the opportunity for vegetable crop diversification in perspective, all U.S. production of nontropical specialty vegetable crops not already grown in California could be produced on less land than is currently in processing tomato production in California's Fresno County alone $(\approx 40,000 \mathrm{ha})$. Viewed in the context of $>900,000$ ha of vegetable production in the West, the opportunity for diversification to specialty or organic vegetables is insignificant. Only improved demand and price for major agronomic crops, or the development of new crops utilized on an industrial scale (for ethanol or fiber production, for example), offer realistic opportunities for economically viable diversification for the vegetable industry as a whole.

Alternative marketing strategies such as direct marketing (through farmers' markets, community-supported agriculture schemes, etc.) and eco-labeling have been advocated as steps toward economic sustainability. Unfortunately, these tools also have limited applicability to the commercial vegetable industry as it exists today. Direct marketing schemes usually require close proximity to the consumer. Given the concentration of the industry in a few western states, these opportunities seem limited. Even within populous California, most vegetable production occurs at considerable distance ( $150 \mathrm{~km}$ or more) from major population centers. While a return to the more geographically decentralized vegetable production that existed before the expansion of irrigation in the West would undoubtedly expand the opportunities for direct marketing, I see no economic force on the horizon likely to cause that decentralization.

Differentiating a vegetable commodity in the marketplace by advertising the methods with which it was grown could result in higher value; the most obvious example of this approach is organically grown produce. There is widespread interest in expanding this principle to include produce grown using practices considered more ecologically sensitive than current conventional techniques (Benbrook et al., 1996), though perhaps not as restrictive as certified organic production. Unfortunately, this is also a limited opportunity. Economic success of this marketing strategy will be limited by the number of consumers willing to pay enough more for the product to cover any additional production and marketing costs incurred, and the willingness of retailers to pass that premium back to the producers. Any success is also likely to be transient, as other producers, desperate to improve profitability, follow suit and saturate that niche market.

Chronic overproduction of nearly all agricultural commodities minimizes market leverage of growers. The continued consolidation of the produce retailing and foodservice sectors in the United States further erodes producer market power, as shown by the ability of chain supermarkets and corporate foodservice operations to demand special services and rebates (Cook, 2002). Until both these issues are addressed, no alternative marketing strategy is likely to have a significant impact on the western vegetable industry as a whole.

In summary, the commercial vegetable industry in California and other western states dominates the U.S. market, and is likely to continue to do so for the foreseeable future. Strictly from the standpoint of production efficiency, there is little objective evidence to convince the current generation of growers that the conventional production practices they currently employ are not sustainable indefinitely. The primary constraints they face are increasingly restrictive government regulation and low profitability; adoption of the alternative practices discussed will largely be driven by the former, and limited by the latter. Any research or educational activity that does not recognize this reality will be largely irrelevant to the existing industry.

\section{Literature Cited}

Andrews, S.S., C.B. Flora, J.P. Mitchell and D.L. Karlen. 2002a. Soil quality indices and farmer's perceptions of organic amendment practices in California. Geoderma. (In press.)

Andrews, S.S., J.P. Mitchell, R. Mancinelli, D.L. Karlen, T.K. Hartz, W.R. Horwath, G.S. Pettygrove, K.M. Scow and D.S. Munk. $2002 \mathrm{~b}$. On-farm assessment of soil quality in California's Central Valley. Agron. J. (In press.)

Benbrook, C.M., E. Groth, J.M. Halloran, M.K.
Hansen and S. Marquadt. 1996. Pest management at the crossroads. Consumers Union, Yonkers, New York.

Bossio, D.A., K.M. Scow, N. Gunapala, and K.J. Graham. 1998. Determinants of soil microbial communities: effects of agricultural management, season, and soil type on phospholipid fatty acid profiles. Microbial Ecol. 36:1-12.

Boydston, R.A. and A. Hang. 1995. Rapeseed (Brassica napus) green manure crop suppresses weeds in potato (Solanum tuberosum). Weed Technol. 9:669-675.

Breschini, S.J. and T.K. Hartz, 2002a. Presidedress soil nitrate testing (PSNT) reduces nitrogen fertilizer use and nitrate leaching hazard in lettuce production. HortScience (In press).

Breschini, S.J. and T.K. Hartz. 2002b. Drip irrigation management affects celery yield and quality. HortScience 37:894-897.

California Department of Food and Agriculture. 2002. Agricultural Commissioner's report data (issued annually from 1986 to 2002). Sacramento, Calif.

California Department of Food and Agriculture. 2000. Fertilizer materials tonnage report (issued annually from 1986 to 2000). Sacramento.

California Department of Pesticide Regulation. 2000. Summary of pesticide use report data, 2000 , indexed by commodity (issued annually from 1990 - 2000). Sacramento, California.

Chaney, W.E. 2001. Insect management for Central Coast lettuce. California Lettuce Res. Board Annu. Rpt. p. 197-212.

Chaney, W.E. 2000. Insect management for the Central Coast. California Lettuce Research Board Annu. Rpt. p. 187-201.

Chaney, W.E., L.R. Wunderlich, and C. Fake. 2000. The Central Coast vegetable IPM project. Available via internet at http://ccvipm.ucdavis.edu

Clark, S., K. Klonsky, P. Livingston, and S. Temple. 1999a. Crop yield and economic comparisons of organic, low-input, and conventional farming systems in California's Sacramento Valley. Amer. J. Alternative Agr. 14(3): 109-121.

Clark, M.S., W.R. Horwath, C. Shennan, K.M. Scow, W.T. Lanini, and H. Ferris. 1999b. Nitrogen, weeds and water as yield-limiting factors in conventional, low-input, and organic tomato systems. Agr. Ecosyst. Environ. 73:257-270.

Clark, M.S., W.R. Horwath, C. Shennan, and K.M. Scow. 1998a. Changes in soil chemical properties resulting from organic and low-input farming practices. Agron. J. 90:662-671.

Clark, M.S., H. Ferris, K. Klonsky, W.T. Lanini, A.H.C. vanBruggen, and F.G. Zalom. 1998b. Agronomic, economic and environmental comparison of pest management in conventional and alternative tomato and corn systems in northern California. Agr. Ecosyst. Environ. 68:51-71.

Colla, G., J.P. Mitchell, B.A. Joyce, L.M. Huyuk, W.W. Wallender, S.R. Tempe, T.C. Hsaio, and D.D. Poudel. 2000. Soil physical properties, tomato yield and quality in alternative cropping systems. Agron. J. 92:924-932.

Cook, R.L. 2002. The U.S. fresh produce industry: An industry in transition, p. 5-30. In: A.A. Kader (ed.). Postharvest technology of horticultural crops, $3^{\text {rd }}$ ed. Univ, of Calif. Publ. 3311 ,

Feibert, E.B.G., C.C. Shock, and L.D. Saunders. 1998. Nitrogen fertilizer requirements of potatoes using carefully scheduled sprinkler irrigation. HortScience 33:262-265.

Flint, M.L. (ed.). 1998. Integrated pest management for tomatoes. Univ. of Calif. Publ. 3274.

Flint, M.L. (ed.). 1985. Integrated pest management for cole crops and lettuce. Univ. of Calif. Publ. 3307. 
Gunapala, N. and K.M. Scow, 1998. Dynamics of soil microbial biomass and activity in conventional and organic farming systems. Soil Biol. Biochem. 30:805-816.

Hanson, B.R. 1995. Practical potential irrigation efficiencies. Proc. $1^{\text {st }}$ Intl. Conf., Water Resources Engineering Div., Amer. Soc. Civi Engineering, San Antonio, Tex., 14-18 Aug.

Hartz, T.K., W.E. Bendixen, and L. Wierdsma. 2000. Pre-sidedress soil nitrate testing as a nitrogen management tool in irrigated vegetable production. HortScience 35:651-656.

Heckman, J.R., T. Morris, J.T. Sims, J.B. Sieczka, U. Krogmann, P. Nitzsche, and R Ashley. 2002. Pre-sidedress soil nitrate test is effective for cabbage production. HortScience 37:113-117.

Heckman, J.R., W.T. Hlubik, D.J. Prostak, and J.W. Paterson. 1995. Pre-sidedress soil nitrate test for sweet corn. HortScience 30:1033-1036.

Horne, J.E. and M. McDermott. 2001. The next green revolution. Food Products Press, Binghamton, N.Y.

Jackson, L.E. 2000. Fates and losses of nitrogen from a nitrogen ${ }^{15}$-labeled overcrop in an intensively managed vegetable system. Soil Sci. Soc. Amer. J. 64:1404-1412.

Jackson, L. and I. Ramirez. 2001. Effects of organic amendments and tillage practices on soil microbial biomass, $\mathrm{N}$ availability and crop yield in intensive agriculture. Ecol. Soc. Amer. Annu. Mtg. (Abstr.)

Jackson, L.E., L.J. Stivers, B.T. Warden, and K.K. Tanji. 1994. Crop nitrogen utilization and soil nitrate loss in a lettuce field. Fertil. Res. 37:93105.

Jackson, L.E. and L.J. Stivers. 1993. Root distribution of lettuce under commercial production: implications for crop uptake of nitrogen. Biol. Agr. Hort. Intl. J. 9:273-293.

Jackson, L.E., L.J. Wyland, and L.J. Stivers. 1993. Winter cover crops to minimize nitrate losses in intensive lettuce production. J. Agr. Sci, 121:5562.

Joyce, B.A., W.W. Wallender, J.P. Mitchell, L Huyck, S. Temple, P. Brostrom, and T. Hsaio 2002. Seasonal changes in infiltration and soil water storage in conventional and alternative agricultural systems. Trans. Amer. Soc. Agr. Eng. (In press).

Karlen, D.L. and A.N. Sharpley. 1994. Management strategies for sustainable soil fertility, $p$. 47-108. In: J.L. Hatfield and D.L. Karlen (eds.). Sustainable agricultural systems. CRC Press, Boca Raton, Fla.

Klonsky, K., R. Kosloff, L. Torte and B. Shouse
2001. Statistical review of California organic agriculture. Univ. Calif. Agr. Issues Ctr., Davis, Calif.

Krueskopf, H.H., J.P. Mitchell, T.K. Hartz, D.M. May, E.M. Miyao, and M.D. Cahn. 2002. Presidedress soil nitrate testing identifies processing tomato fields not requiring sidedress $\mathrm{N}$ fertilizer. HortScience 37:520-524.

Lewis, W.J., J.C. van Lenteren, S.C. Phatak, and J.H. Tumlinson. 1997. A total system approach to sustainable pest management. Proc. Natl. Acad. Sci. 94:12243-12248.

Livingston, P.L. 1995. A comparison of economic viability and measured energy required for conventional, low-input and organic farming systems over a rotation period. MS Thesis, California State Univ., Chico.

Lundquist, E.J., L.E. Jackson, K.M. Scow, and C. Hsu. 1999. Changes in microbial biomass and community composition, and soil carbon and nitrogen pools after incorporation of rye into three California agricultural soils. Soil Biol. Biochem. 31:221-236.

MacDonnell, L.J. 1999. From reclamation to sustainability. Univ. Press of Colorado, Niwot.

Martini. E. 2001. Soil characteristics and crop performance in a processing tomato-maize rotation during the transition from conventional to organic management. MS thesis, Univ. Calif., Davis, Calif.

Mitchell, J.P., P.B. Goodell, R. Krebill-Prather, T.S. Prather, K.J. Hembree, and D.S. Munk. 2001. Innovative agricultural Extension partnerships in California's central San Joaquin Valley. J. Ext. 39(6), electronic journal available at http:/ Ljoe.org .

Miyao, G. and P. Robins. 2000. Influence of fallplanted cover crop on rainfall run-off in a processing tomato production system. Acta Hort. 542:343-345.

Monterey County Agricultural Commissioner. 2000. Monterey County Annual Crop Report (issued annually from 1986 to 2000). Salinas, Calif

Olivier, C., S.F. Vaughn, E.S.G. Mizubuti, and R. Loria. 1999. Variation in the allyl isothiocyanate production within Brassica species and correlation with fungicidal activity. J. Chem. Ecol. 25:2687-2701.

Perrin, R.M. 1997. Crop protection: Taking stock for the new millennium. Crop Protect. 16:449456.

Poudel, D.D., H. Ferris, K. Klonsky, W.R. Horwath, K.M. Scow, A.H.C. VanBruggen, W.T. Lanini, J.P. Mitchell, and S.R. Temple. 2001. The sustainable agriculture farming system project in
California's Sacramento Valley. Outlook Agr. 30(2):109-116

Reisner, M. 1993. Cadillac desert. $2^{\text {nd }}$ ed. Penguin Books, New York.

Sojka, R.E. and D.R. Upchurch. 1999. Reservations regarding the soil quality concept. Soil Sci. Soc. Amer. J. 63:1039-1054.

Subbarao, K.V, 1998. Progress toward integrated management of lettuce drop. Plant Dis. 82:10681078 .

Toscano, N.C. S.J. Castle, T.J. Henneberry, and N.P. Castle. 1998. Persistent silverleaf whitefly exploits desert crop systems. Calif. Agr. 52(2):29-33

Trumble, J.T. 1998. IPM: Overcoming conflicts in adoption. Integrated Pest Management Rev. 3:195-207.

Trumble, J.T., W.G. Carson, and K.K. White. 1994. Economic analysis of a Bacillus thuringiensisbased integrated pest management program in fresh-market tomatoes. J. Econ. Entomol 87:1463-1469.

U.S. Department of Agriculture, Economics Research Service. 2001. Vegetables and specialties situation and outlook. Washington, D.C.

U.S. Department of Agriculture, National Agricultural Statistics Service. 2002a. Vegetables, 2001 summary. Washington, D.C

U.S. Department of Agriculture, National Agricultural Statistics Service. 2002b. Crop production, 2001 summary. Washington, D.C.

VanBruggen, A.H.C. 1995. Plant disease severity in high-input compared to reduced-input and organic farming systems. Plant Dis. 79:976-984.

Workneh, F. and A.H.C. VanBruggen. 1994. Microbial density, composition, and diversity in organically and conventionally managed rhizosphere soil in relation to suppression of corky root of tomatoes. Agr. Ecosyst. Environ. 1:219 230.

Wyland, L.J., L.E. Jackson, and K.F. Schulbach 1995. Soil-plant nitrogen dynamics following incorporation of a mature rye cover crop in a lettuce production system. J. Agr. Sci. 124:1725.

Wyland, L.J., L.E. Jackson, W.E. Chaney, K Klonsky, S.T. Koike, and B. Kimple. 1996. Winter cover crops in vegetable cropping system: impacts on nitrate leaching, soil water, crop yield, pests and management costs. Agr. Ecosyst. Environ. 59:1-17.

Zalom, F.G., W.T. Lanini, G. Miyao, and R.M. Davis. 2000. A continuum of integrated pest management practices in processing tomatoes. Acta Hort. 542:55-62 